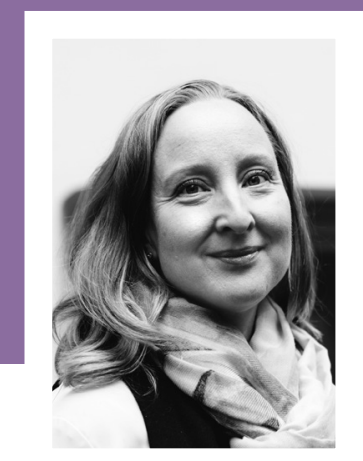

\title{
P̈̈̈̈KIRJOITUS
}

\section{KiRJOITTAESSASI ET OLE KOSKAAN YKSIN}

K IRJOITTAMINEN ON KESKEINEN ja välttämätön osa tutkimus- ja asiantuntijatyötä. Keskittymistä ja luovuutta vaativissa kirjoitustöissä tarvitaan sekä riittävästi aikaa että kirjoitusprosessia ylläpitäviä rutiineja. Haasteena voi olla oikeanlaiseen mielentilaan pääseminen - varsinkin, jos kirjoittamisen kanssa kilpailevat monet muut työn ja vapaa-ajan velvollisuudet.

Korkeakoulutusta ja akateemista kirjoittamista tutkinut apulaisprofessori Barbara Mary Grant (2006) on todennut, että moni turhautuu suunnitellessaan kirjoitusprojektejaan pääsemättä kuitenkaan koskaan kunnolla työn imuun. Niin moni asia tuntuu olevan meidän ja kirjoittamisen välissä. Ratkaisuna ongelmaan Grant toteuttaa erityisesti naisille suunnattuja Women Writing Away (WWA) -kirjoittamisretriittejä Uudessa-Seelannissa. Ideana on rauhoittaa aikaa muilta aktiviteeteilta vain tekstien työstämiseen, osana kirjoittajayhteisöä.

Grantin esimerkin innoittamina toteutimme pienen työporukan kesken kirjoitusmatkan Tarttoon pari vuotta sitten. Matkan aikana syntyi aivan erityinen tunnelma, jota fyysinen etäisyys arjesta vahvisti. Jokainen työskenteli intensiivisesti oman kirjoitusprojektinsa parissa, mutta ajatukset ja tekstit eivät jalostuneet yksin eivätkä tyhjiössä. Tekstin parissa työskentelyyn yhdistyivät keskeneräisten tuotosten lukeminen ja kommentointi sekä kirjoittamiseen liittyvät lyhyet alustukset ja harjoitukset. Hiljainen talo oli täynnä työtovereita, jotka tekivät samaa työtä ja jakoivat tekstin luomisen ilon, tuskan ja nautinnon.

KIRJOITTAMINEN EDELLYTTÄÄ LUKEMISTA, keskustelua ja akateemisten tekstilajien ja ilmaisumuotojen opettelemista (Vilkka 2020). Omiin teksteihimme kietoutuvat kasvatuksen, koulutuksen ja muiden sosiaalisten yhteisöiden välityksellä meitä ympäröivät kulttuuriset ajattelutavat ja käytännöt. Kirjoittajina kasvamme yhteisön jäseniksi ja omaksumme erilaisia tekstin tuottamisen tapoja, kuten Melisa Stevanovic kumppaneineen tässä numerossa havainnollistaa. Omissa teksteissämme kulkevat mukana opettajiemme, arvostamiemme tutkijoiden ja yhteistyökumppaneidemme kirjoitukset.

Omaperäisetkään aikuiskasvatuksen tutkijat, filosofit ja aikalaiskriitikot eivät päädy uusiin avauksiinsa yksin, ilman muiden ajattelun vaikutusta. Tekstit tuovat maailmaan jotakin yllättävää toistensa varassa muodostuvien rihmastoja avulla, liittämällä asioita aiempaan tieteelliseen keskusteluun (esim. Vilkka 2020).

Kirjoittaminen uudella tavalla edellyttää sitä, että astuu tuttujen piirien ulkopuolelle ja uskaltaa heittäytyä vuorovaikutukseen "marginaalissa" olevien kanssa. Ehkä matkustamista, muuttoa, työpaikan vaihta- 


\section{HILJAINEN TALO OLI TÄYNNÄ TYÖTOVEREITA,}

\section{JOTKA JAKOIVAT SAMAN TEKSTIN LUOMISEN ILON,}

TUSKAN JA NAUTINNON.

mista. Altistumista eroille ja erilaisuudelle. Kirjoituksemme liikahtavat eteenpäin nimenomaan siksi, että törmäytämme vanhaa ja uutta kiinnostavien kohtaamisten kautta.

Lukija on aina läsnä kirjoittamisessa. Suuntaamme viestimme ja perustelemme väitteemme oletetulle lukijalle, käymme mielikuvissamme dialogia hänen kanssaan.

Kirjoittaessa voi miettiä ja vaikka konkreettisesti nimetä, kenen haluaisi me lukevan valmiin julkaisun. Mistä olemme oletettavasti samaa mieltä? Mistä lukija luultavasti yllättyy ja mitä hän epäilee? Jotkin väitteet kenties vaativat erityistä perustelua. Ennen kaikkea on mietittävä, mitä toivomme lukijan saavan lukemisesta irti ja millaista keskustelua haluamme herättä.̈. Onnistuessaan kirjoituksemme tarrautuvat kiinni lukijoidemme ajatteluun ja akateemiseen työhön aivan samoin kuin meitä ovat liikuttaneet meitä edeltäneet tekstit.

TÄSSÄ NUMEROSSA halusimme tehdä näkyväksi tekstien intersubjektiivisuutta ja intertekstuaalisuutta julkaisemalla väitöskirjatutkija Mikko Rosenbergin artikkelin rinnalla käsikirjoituksen vertaisarvioineiden tutkijoiden Touko Vaahteran ja Tuure Tammen kommentit. Toimitusprosessin aikana vertaispalautteen ja käsikirjoituksen tekstin välille syntyi hedelmällinen vuoropuhelu. Prosessi ilmensi esimerkillisesti kirjoittamisen dialogisuutta ja uuden syntymistä jakamisen kautta.

Aikuiskasvatuksessa arvioitsijoiden ja toimituskunnan tehtävänä on haastaa ja kannustaa kirjoittajia kirkastamaan ajatuksiaan ja ilmaisuaan. Rakentava palaute on lahja, josta tulee osa tekstiä, kun tekijä muokkaa sitä. Kirjoittamistyötä kannattelee kirjoittajien ja lukijoiden yhteys tekstien äärellä ja teksteissä.

Ulpukka Isopahkala-Bouret

\section{Lisää aiheesta:}

Grant, B. M. (2006). Writing in the company of other women: Exceeding the boundaries. Studies in Higher Education 31(4), 483-495. DOI: 10.1080/03075070600800624.

Vilkka, H. (2020). Akateemisen lukemisen ja kirjoittamisen opas. Jyväskylä: PS-kustannus. 